\title{
Improving Students Writing Anecdote Skill Through Scientific Method In The First Grade Students Of SMAN 3 Praya
}

\author{
Evi safitri yulandari \\ Pendidikan Bahasa Inggris, Institut Pendidikan Nusantara Global \\ Email Korespondensi: evisafitri785@gmail.com
}

\begin{abstract}
Abstrak. This study was aimed to know the writing anecdote skill in the first grade students of SMAN 3 Praya, the researcher chose the anecdote as the material because there are 13 kind of text in English, but anecdote is rarely taught by the teacher whereas anecdote is interesting story about a real incident or person and the students may interested when they learn about anecdote text. This research used scientific method, The term "Scientific Method" gained its popularity in the field of education in Indonesia when Curriculum 2013 was launched by Ministry of Education and Culture in 2013, It is explicitly stated in the curriculum that, with its excellences, the scientific method is very important for a better quality of teaching and learning to develop students' affection, knowledge, and skills. The researcher did a qualitative case study with the total 30 students' involved as well as participant. This study used several data instrument in gathering the data dealing with the question of the study, i.e: observation, interview and questionnaire form to collect the data in a case study to explore (1.) whether or not the teacher is able to implement scientific method to teach writing anecdote skill; (2) how the teacher interprets scientific method; (3) the students' perception toward anecdote text and scientific based learning activity. This research might be the window for further studies or reference to explore the potential benefit and challenge of scientific method in teaching writing anecdote text, particularly for senior high school level.
\end{abstract}

Keyword: writing; anecdote; scientific method

\section{INTRADUCTION}

Writing is one of important skills for foreign language learners in learning English. It is important because writing is a crucial skill for academic or occupational success. Next, writing can be an effective tool for the development of academic language proficiency as learners have to explore advanced lexical or syntactic expression in their written work. The last is writing across the curriculum that can be invaluable for mastering diverse subject matter. Therefore, it can be said that writing is the primary basis upon which our work and study will be judged in school or college, in the workplace, and in the community.

Britton (in Laksono, 2015: 2) states that writing success is influenced by the writer's understanding of the readers of his writing. This ability allows us as writers to choose information and how to present it accordingly. It's same like writing anecdote texts, the writer is not only able to convey satire or criticism in his writing, but also must be able to create humorous value in order to attract the attention of the reader. This anecdote text is a funny story that aims to convey criticism of the character being told. Wardani (2017: 46) states that anecdote text is a short story, but funny and the content is satire. The figures told can be well-known or factual in nature. According to Darmawati (2016: 100), anecdotes have a structure that differentiates them from other kind of text. Anecdote structure is divided into five, namely abstract, orientation, crisis, reaction, and code. The abstract is at the beginning of the anecdote. Writing anecdote texts listed in KI 4 (contents competence) and KD (basic competence) 4.6. In KI 4, students' process, reason, and present in the realm of the concrete and the abstract realm related to the development of what they learn in school independently, and are able to use methods according to scientific principles. In KD 4.6 students recreate anecdotal texts by paying attention to structure and language.

This research is concerned with investigating a teacher's implementation of 
scientific method to teach writing anecdote text at senior high school level as it is required by the 2013 English curriculum. The term "scientific method" has come along in the development of English language teaching for junior high school, senior high school, and vocational high school since the introduction of the 2013 curriculum as the new "umbrella" of schooling system in Indonesia. Scientific method in learning is considered the procedure of acquiring learning outcomes which values much on the process of learning and student-centeredness so that it can facilitate and develop students' cognitive, affective, and psychomotor capability. As the new curriculum has been initiated, the use of scientific method becomes prominent with regards to the decree of Minister of Education and Culture No. 69/2013 that requires the integration of scientific method into all subjects including English language teaching. Consequently, English teachers currently are required to conduct successful instruction through scientific method in order to help students gain their target language mastery.

Concerning scientific-based learning activities that require the students to do activities such as comprehending the given information, expressing and deliberating some questions, collecting and noting piece of information and presenting their ideas to the peers, the researcher views that the model of teaching through scientific method shares similar characteristic to cognitive approach to language teaching which integrates stimulating tasks to be dealt by students in learning the target language.

\section{RESEARCH METHODS}

Qualitative case study methodology provides tools for researchers to study complex phenomena within their contexts. This study used daring as a media to teaching and learning process and qualitative data gathered from analysis of students writing essay and interview. In line with this Denzin and Lincoln (2005) describe that data are about feelings, opinions, expectation, suggestions, and preferences from the research members and the students related to the method that was used in teaching and learning writing. Furthermore, qualitative researchers study things in natural settings, attempting to make sense of or interpret phenomena in terms of the meanings people bring to them."'When applying qualitative research methods, the emphasis is put on the natural setting and the points of views of the research participants. The data has been collected using observation, interview and questionnaire.

In this research the researcher also used saintific method to teach the students writing anecdote text. As the introduction of 2013 curriculum has just been initiated recently, the transition of the approach to teaching and learning process required by the curriculum becomes a considerable challenge for language teachers as far as it is concerned with the level of classroom practice because they have to learn new method required by the curriculum. The problem seems to be worse since there are some evidence that indicate some teachers were not capable in composing material and lesson plan for teaching. Study conducted by Suhendra \& Sundayana (2011) revealed that teachers' knowledge in developing syllabus was not satisfying. Further, Sundayana et. al, (2012) found out that teacher's conceptual understanding of designing, developing, and applying syllabus and lesson plan did not reach the expectation. During the first year of the implementation of the 2013 Curriculum, it was noticed that some teachers faced difficult time in administering the instruction based on scientific method so that they were not likely to teach English effectively in the classroom. Instead, they showed some resistance and keep teaching by using the technique they are already comfortable with. Because of those reason above the researcher hope this research could become one of the resource for the teacher or another researcher who want to conduct further research related to writing anecdote and scientific method.

The subject of this study was the first grade students of SMAN 3 Praya in the academic year 2020/2021. There was only one class consisted of 30 students. 
To gather the data needed in this research, the instruments consist of observation, interview and questionnaire. Writing anecdote text was employed when the teacher finish teach the students two or third time by using scientific method, so the students were more adjust with the material that they learn. The teacher asks the students' what their think and feels when they learn to write anecdote text by using scientific method in teaching and learning process, and the students would answer the questions in the form of interview and questionnaire.

In the interview guide, some questions were written to guide the interview. Since this study employed a semi-structured interview, the prepared questions in the interview guide were possible to be developed when the interview was done. The interview guide was employed to gather more information from the students regarding during study that they implemented, were they like to learn writing anecdote through scientific method or not in teaching and learning process.

To analyze the data of this study, the model of data analysis procedure

suggested by Miles \& Huberman

(1994) was employed in this study.

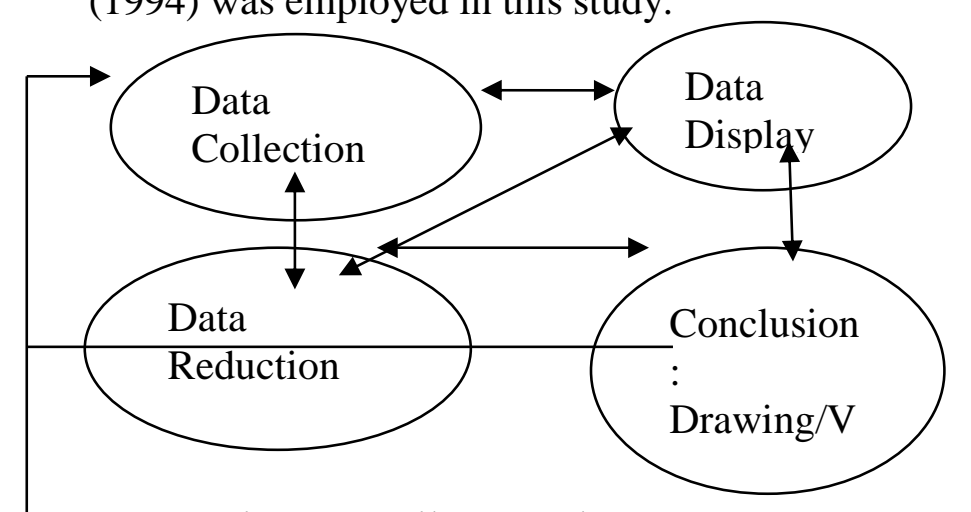

Figure 1. Miles \& Huberman's Analysis Model (1994)

\section{RESULTS AND DISCUSSION}

In this discussion, was explained: (1) the skills of writing anecdote text in the first grade students of SMAN 3 Praya before using the scientific method and (2) the students writing anecdote text skills through scientific method of the first grade students of SMAN 3 Praya.
The skills of writing anecdote text in the first grade students of SMAN 3 Praya before using the scientific method

Anecdotal text writing skills in the first grade students of SMAN 3 Praya based on the average count of the three indicators are 79.28 with a Good qualification (B) because they are in the $72-79 \%$ range on a scale of 10 . This is because students are still less capable expressing ideas, thoughts, and rarely get practice writing during the learning process. The inability of this student is more visible in the average count indicator of the content of the text of 72.16. In accordance with the opinion of Semi (2009: 17) that writing activities aim to provide direction, explain something, tell events, summarize, and convince readers. Therefore the teacher must provide training and motivation to students to write more. Furthermore, data analysis of anecdotal text writing skills in the first grade of SMAN 3 Praya showed the average count of the three indicators, the text structure (79.31), the qualifications were Good (B), the text content (72.16), the qualifications were Good (B) , and diction $(78,38)$ with Good qualification (B). From this analysis, the most errors made by students were found in the text content indicator (3) with an average value of 72.69 and the least errors made by students were on the text structure indicator (1) with an average value of 85.31. Most of the students were able to write anecdotal texts based on the complete structure of the anecdotal text. This is in line with Darmawati's (2016: 100) opinion, that the structure of anecdotal text is divided into five, namely abstract, orientation, crisis, reaction, and code. The most mistakes made by students were in the text content indicator with an average score of 77.19. Based on the assessment criteria carried out on student writing, it can be seen that students are still less able to present or convey funny, critical events in anecdotal texts that make readers interested in what they are telling. The inability of students to convey their ideas is due to a lack of knowledge about things that occur in their environment and lack of mastery of vocabulary. Starting from the results of the students 'anecdotal text writing assessment, it 
can be concluded that the students' anecdotal text writing skills, especially for indicators of text content as a tool for attracts readers, is not achieved. This is in accordance with the initial findings as described in the section on the background of the problem. In students' writing, it appears that the writer is not able to put his ideas well. The author only provides a statement in accordance with the given context which proves that basically the author does not understand what he should express in the writing. This failure can be attributed to the weakness of the crisis section of the anecdotal text is the climax of the story. In that section, you can see the contents of the anecdotal text which are funny and critical. However, students are not able to convey that part well because lack of understanding of the meaning of the anecdotal text.

\section{The students writing anecdote text skills through scientific method in the first grade students of SMAN 3 Praya.}

Based on the results of the research and the results of data analysis, it is known that the skills of understanding anecdotal text in the first grade students of SMAN 3 Praya are classified into three categories, namely perfect, excellent, and good. The average value of anecdotal text comprehension skills in the first grade students of SMAN 3 Praya after the researcher used scientific method was 86.45 with a mastery level (86-95\%) are in very good qualifications on a scale of 10 . Based on the average scores obtained, it can be said that most students have begun to be able to understand the structure and content of the text read by students by using this method. Students already understand the structure of the text they read starting from abstract, orientation, crisis, reaction, and code. According to Agustina's opinion (2008: 15), reading comprehension is reading that is done without making sound. This types of reading does not require the reader to read or correct the reading, but only to use the eyes to see and the heart and mind to understand it. Read this understanding includes intensive reading. This means that readers must be serious in studying the content of the reading and concentrate on what they read. The indicator most mastered by students is the indicator of determining diction with value an average of 87.38 with a mastery level (86-95\%) is in very good qualification on a scale of 10 . Based on the average value obtained, it can be said that most students have begun to be able to understand and determine the right diction in the text they read, this can seen by the interview that the researcher did with the teacher and also with the students and this also can be seen from the scores obtained by students with an average of good qualifications once. The lowest student mastery is on the indicators determining the structure of the anecdotal text read by students, this can be seen by the questionnaires that have been filled in by students, and most students said they had difficulty in structuring the sentence to make good anecdote text. The students' mean score was 78.49 with a level of mastery (76-85\%) are in good qualification on a scale of 10. Based on this average score, it can be said that students have begun to be able to understand the structure of the text they read. Based on this discussion, it can be concluded that the value of the skills in understanding anecdotal text in the first grade students of SMAN 3 Praya is very well qualified. Therefore, in general, students can be said to have understood about the structure, content, and diction of anecdotal texts through reading activities. This is in line with the objectives read the understanding put forward by Agustina (2008: 15) which says that reading comprehension aims to capture the meaning of the ideas that exist in reading. This is in line with the implementation of the objective tests used for measuring the skills of understanding anecdotal text in the first grade students of SMAN 3 Praya, in the implementation of the test some of the first grade students in the SMAN 3 Praya had involved a thought process in analyzing each question that given by the teacher.

\section{CONCLUSION}

Based on the results of this research, the following three points were concluded. First, writing skills anecdote text for the first grade students is in a good qualification (B). 
This is because students are still doesn't able to express ideas, thoughts, and seldom get practice writing during the learning process. Second, the skills to understand anecdote texts for the first grade students are in a very good qualification (A). This is because most students have already able to understand the structure and content of the text they read after the teacher using scientific method. Students already understand the structure of the text they reads from abstract, orientation, crisis, reaction, and code. Third, there is a significant relationship between anecdote writing text skills with using scientific method of the first grade students on $84 \%$ confidence level. This is means if the understanding the material by using scientific method for the students higher, then the writing of anecdote text skills will also higher for the first grade students. On the contrary, if the understanding the materials by using scientific method are poor, then text writing skills the student anecdote will also bad.

\section{SUGGESTION}

Based on the conclusions obtained from the results of this research, the suggestions are put forward as following. First, it is suggested to the first grade students' teachers to train students' understanding and writing skills by using scientific method, especially in learning anecdote texts, and it is also hoped that teachers will further facilitate students to improve reading comprehension skills and anecdote text writing skills. Second, for the first grade students, they are expected to be more serious learning comprehension skills and anecdote text writing skills take place. In addition, students are also expected to practice more and more in skills understand and anecdote text writing skills. Third, it is suggested to other researchers. This study is how to used scientific method conduct research related to writing and anecdote text.

\section{BIBLIOGRAPHY}

Agustina. 2008. "Pembelajaran Keterampilan Membaca". Buku Ajar. Padang: Jurusan Bahasa dan Sastra Indonesia FBS UNP.
Darmawati, Uti dan Budi Artati. 2016. Bahasa Indonesia Kelas X Wajib. (Buku Siswa). Klaten: Intan pariawara.

Denzin, N. K., \& Lincoln, Y. S. (2005). Introduction: The Discipline and Practice of Qualitative Research. In N. K. Denzin \& Y. S. Lincoln (Eds.), The Sage handbook of qualitative research (p. 1-32). Sage Publications Ltd.

Laksono, Ambar Tri. 2015. "Peningkatan Keterampilan Memproduksi Teks Anekdot dengan Model Pembelajaran Role Playing "Pelayanan Publik" pada Peserta Didik Kelas X Multimedia 3 SMK Negeri 8 Semarang." Jurnal Pendidikan Bahasa dan Sastra Indonesia, Vol 4 No. 1. Diunduh pada 20 Juli 2018.

membaca berdasarkan Model PISA 2009 bagi Siswa SMP RSBI di Jawa Barat. Jakarta: Pusat Penilaian Pendidikan Depdiknas

Miles, M.B, and Huberman, A.M. (1994). Qualitative Data Analysis, 2nd Ed., p. 10-12. Newbury Park, CA: Sage.

Suhendra, Y. \& Sundayana, W. (2011). Pengembangan model bahan ajar literasi

Sundayana, W., Alwasilah A.C. et al. (2012). Pemahaman konseptual guru

terhadap desain, pengembangan, dan penerapan perangkat pembelajaran.

Wardani, dkk. 2017. "Studi Kasus Pembelajaran Menulis Teks Anekdot pada Kurikulum 2013 di SMA Negeri 1 Surakarta". Aksara, Vol 2 No.1. diunduh pada 26 Februari 2018. 